\title{
The Role of Teachers in Implementing Multicultural Education Values in the Curriculum 2013 Implementation in Indonesia
}

\author{
-Suryaman: Universitas Islam Raden Rahmat, Jl. Mojosari 2, Kepanjen, Malang, Indonesia. \\ Juharyanto: Universitas Negeri Malang, Jl. Semarang No. 5, Sumbersari, Malang, Indonesia.
}

ABSTRACT: This study wants to examine the role of teachers in implementing the values of multicultural education in the curriculum 2013 implementation in primary education. The method of this research is descriptive qualitative. Data were collected through observation, interviews, and documentation. The informants in this study were the Principal, Vice Principal for Public Relations, Teachers, Students, and parents. The research showed that the school has a pattern as a multicultural public school. Teachers have a role in integrating multicultural values into the preparation of lesson plans, the application of fun learning, and the accommodation of diversity of students of different religions.

Key words: Teachers' role, Multicultural education values, Curriculum 2013.

\section{Introduction}

The Indonesian nation is a nation whose society is very plural or pluralist (Lestari, 2015). Pluralism has become a characteristic of the Indonesian people. This plurality can be seen from two perspectives, namely: horizontal and vertical perspectives. In a horizontal perspective, the diversity of our nation can be seen from differences in religion, ethnicity, regional, geographical, and cultural languages. Whereas in a vertical perspective, the diversity of the Indonesian nation can be seen from the differences in education, economic, and socio-cultural levels. Schools as formal education institutions have responsibility for the success of cultivating multicultural education values to students. The existence of the school is to prepare the young generation for the future (Amirin, 2012; Syam, 2009). When plunging in society they must be prepared to face a pluralist situation. The school should aware that students are clearly difference. They are coming from different background (Nuhoğlu \& İmamoğlu, 2019). The school has a lot of tasks to facilitate students to have good understanding of the situation in a multiethnic society (Banks, 2016; Banks \& Banks, 2009). When studying in school, students must be taught new paradigms and deep beliefs about multiculturalism (Dale \& Hyssop-Margison, 2010; Hernandez, 1989; Suryaman \& Karyono, 2018). Teachers must be able to integrate multicultural values in learning and use teaching methods that are relevant to multiethnic and multisocial situations (Suryaman \& Karyono, 2018), as has been developing in the curriculum 2013, that all schools should implement it into the school daily programs and activities.

Curriculum 2013, is not just a new curriculum which is a simplification of the previous curriculum. Curriculum 2013 is prepared and developed to maximize the learning process constructively and adaptively to the overall potential variants of individual students (Juharyanto \& Imron Arifin, 2018). The curriculum 2013 bases itself on an important awareness of the difference facilities and facilitates these differences maximally, individually, and is developed in the integrity of the learning process (Suryaman \& Karyono, 2017). The

\section{Studies}

2020

DOI: $10.53935 / 2641-533 x . v 3 i 2.139$

Corresponding Author: Suryaman

Funding: This study received no specific

Received: 8 April 2020

Revised: 12 May 2020 Publishing Group 
principles of pluralism are an important foundation for the success of the learning process. Students' awareness of diversity and pluralism, both individually, socially, culturally, and economically, is a necessity of goals that must be achieved by schools, especially students (Agus, 2016). In this framework, the teacher has an important role, not only as a learning facilitator, but also as a form of multicultural models that appear before their students, displays dan share the multicultural echoes to all of their students.

In school, the teacher has a very central role in implementing multicultural values. The successful implementation of multiculturalism in early childhood classes, his responsibilities tended to depend largely on the shoulders of teachers who were individuals who were seen by children as role models and role models Juharyanto (2012). Therefore, teachers are expected to have new paradigms and deep beliefs to instill the importance of understanding diversity, especially for their new future era (Baykova \& Vlasova, 2019). The teacher is the spearhead of the development of multicultural education (Arends-Tóth \& van de Vijver, 2000).

The role of the teacher is very decisive in the success of encouraging cross-cultural understanding of students (Anderson, Swick, \& Yff, 2001; Meirink, Meijer, \& Verloop, 2007). What the teacher conveyed, the way the teacher taught, and the personality of the teacher greatly influenced the success of learning. Likewise, the cultural background of the teacher will also shape students' perceptions of their culture (Villegas \& Lucas, 2002; Zhu \& Zeichner, 2013). Teachers who do not understand their own cultural background and are not culturally sensitive or do not have cross-cultural understanding cannot be expected to succeed in implementing multicultural education (Banks, 2016; Suryaman \& Karyono, 2018). Therefore, it is very important to prepare teachers to have a cross- cultural understanding, so that they are able to hold a multicultural education. Because, teachers are actually involved in schools' activities with their multicultural backgrounds.

In teaching and learning activities in schools' teachers need to have learning strategies that meet their goals (Meirink et al., 2007). Strategies that need to be used are various such as: discussion, simulation, role playing, observation, case studies, problem solving. Through discussion the teacher can provide suggestions and obtain information from students about the contribution of various cultures and people from other tribes in living together as a nation. Learning with this discussion can exchange ideas that everyone from any culture turns out to use results (Jablonski, 2013).

Multiculturalism is a concept of culture, and because the process of education is a civilizing process, multicultural society can be created through the education process. Education and civilization are a process of character building (Arifin, Juharyanto, Mustiningsih, \& Taufiq, 2018; Juharyanto, 2014). Multicultural education is education based on multiculturalism. Multicultural education as a perspective that recognizes the social, political, and economic realities experienced by each individual in complex and diverse human encounters, and reflects the importance of culture, race, sexuality and gender, ethnicity, religion, social status, economy, and exceptions in the education process (Hernandez, 1989; Suryaman \& Karyono, 2018).

The implementation of multicultural education in schools has several specifications. Banks stated that schools that have a commitment to develop pluralism must appear in: (1) developing respect for school activities for ethnic diversity, (2) developing cohesiveness based on joint participation from several cultural groups, (3) providing maximum opportunities for all individuals and groups; and (4) facilitating constructive change that can enhance the dignity and ideals of democracy (Peris-Ortiz \& Merigo, 2015; Uitermark, Rossi, \& Van Houtum, 2005; Uzum \& Avineri, 2019). The learning process carried out by teachers in schools needs to pay attention to the above aspects in following ways: first, teaching is not just saying words, but need to give students the opportunity to develop and actively seek and process knowledge/information obtained, so that it becomes an integrated understanding with the knowledge and experience possessed by students; second, the development of culture so that it can be well understood and is in accordance with the reality of the lives of students, thirdly, students come to school with their initial knowledge, so that learning must be able to link new concepts with the experience they have (Agus, 2016).

\section{Method}

The design of this study uses a qualitative approach, that produces descriptive data in the form of speech or writing and observable behavior from people or the subject itself. The presence of researchers as a key instrument to give meaning to phenomena clearly and act actively in the entire research process. The

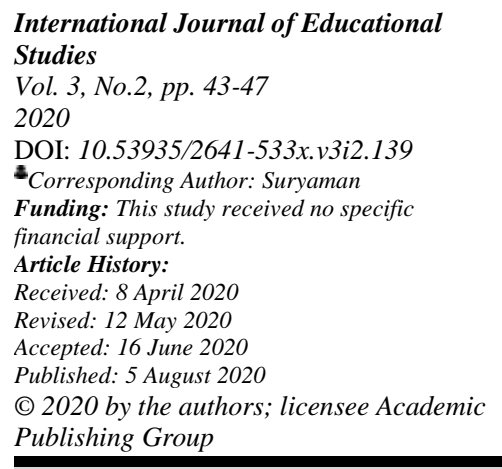


informants of this study included principals, teachers, students, and parents in primary education in Indonesia.

Data collection is done by the technique of participant observation, in-depth interviewing, and documentary study. Data analysis is an activity to find and systematically collect data obtained from field notes, interviews, and other material, so that findings can be understood and informed to others. The researcher conducts the process of interpreting and summarizing the data. Furthermore, the validity of the data was tested through triangulation techniques.

Primary school in Indonesia is a multicultural school. As a public school, all Schools respect religious differences as a force of unity and mutual respect by accommodating 5 (five) religions (Islam, Christianity, Catholicism, Hinduism and Buddhism) and providing religious teachers according to the beliefs and beliefs of each student, packaged into the Core Competencies developed by SD Development include: 1) Science; 2) Workshop of Entrepreneurship; 3) Liberal Art; 4) Sustainable Eco Development.

This superior curriculum is developed based on the principles: centered on potential, development of the needs and interests of students and the environment; diverse and integrated; responsive to the development of science, technology and art; relevant to life's needs; comprehensive and continuous; lifelong learning; and balanced between national interests and regional interests.Based on these brief descriptions, this study focuses on the roles played by teachers in accommodating all multicultural differences into the overall practice of education and teaching in primary education.

\section{Results and Discussion}

There are several important results' findings in this study as explained below:

1. Primary education in Indonesia, in general, strive to optimally shape students to love learning, creative, independent and have noble character, especially in the context of the globalization era in multicultural perspective.

2. The Elementary multicultural schools, emphasize high appreciation for diversity, one of which accommodates 5 (five) religions (Islam, Christianity, Catholicism, Hinduism and Buddhism) and provides religious subject teachers in accordance with their respective beliefs and beliefs students.

The curriculum 2013 implementation and excellent innovative learning methodologies are integrated to fun learning in the basis of multicultural values.

3. The preparation of multicultural learning designs are done through five main stages, they are: (1) content analysis (content analysis); (2) cultural background analysis (setting analysis); (3) material mapping; (4) organizing learning material; and (5) pouring in the learning format. The five stages of the process in formulating the learning design can be described as follows:

a. Content analysis, the process of identifying, selecting, and establishing learning materials based on core competencies and basic competencies.

b. Cultural background analysis is developed from a cultural and life cycle approach, which contains two concepts, they are the internally contextual concept (local, regional, national and global); and human concepts and activities that cover all aspects of life. In addition, background analysis also considers cultural values that grow, develop and are held in high esteem by a community and the possibility of their usefulness for the lives of students.

c. Mapping the learning material that is closely related to values and morals, and done through these principles: from easy to difficult; from simple to difficult; from concrete to abstraction; from a narrow/close environment to a broad environment.

d. Organizing multicultural-based material, taking into account the content/material dimension, the dimension of knowledge construction, the dimension of prejudice reduction; dimensions of education that are equal/equitable (equitable pedagogy), and dimensions of empowering school culture and social structures.

e. Develop a multicultural based student-centered lesson plan, with the openly facilitate the students to maximally construct their maximum learning as in the curriculum 2013 design.

Based on the research findings, it can be argued that the assessment of multicultural education needs is essentially a natural thing in a pluralistic community. That is the desire to organize multicultural education usually appears in a pluralistic society that realizes its plurality (Bakken, Obiakor, \& Rotatori, 2014; Juharyanto \& Imron Arifin, 2018). Such a society realizes that it consists of various groups that are 
ethnically, socio-economically, and culturally different. This society is often called a pluralistic or heterogeneous society (Nuhoğlu \& İmamoğlu, 2019). Education, from the view of pedagogical disciplines, it was suggested that for the Indonesian context, multicultural education was only a discourse (McGee Banks \& Banks, 1995).

Since 2002 until now the multicultural education discourse has blown in Indonesia. This trends then become a basis and philosophic approach of the implementation of curriculum 2013.

Educational institutions (schools) are seen as one instrument that is able to instill multicultural education from an early age. Education is a potential entry point to minimize conflict, then the first thing to do is cultivating the awareness of the community for plurality, equality, humanity, justice and democratic values in a variety of social activities (Chang, Pak, \& Sleeter, 2018). As a preliminary overview, the world of education has preventive roles for the integration of these values and prevent the multicultural values thread.

The phenomenon of curriculum development in multicultural schools needs special management and need for curriculum modification so that it contains more content of tolerance and appreciation for other cultures and groups (Lawyer, 2018; Uzum \& Avineri, 2019). Embedding tolerant and appreciative-inclusive attitudes can be done in two ways. First, inserted in the subjects of Religion and Citizenship. The rationale is that tolerance and appreciation for pluralism and difference are an integral part of an inclusive religious attitude and how to behave in polite as civilized citizens. So, the subjects of Religion and Citizenship cannot abandon tolerance education (Rahman, 2017). Second, given independently in separate subjects, for example with the name Peace Education (Nakaya, 2018; Uzum \& Avineri, 2019). The rationale is because if it is only inserted in other subjects, it is feared that cultivating tolerant and inclusive attitudes will not receive priority. One of the research findings is in relation to efforts to create a climate of teaching and learning activities in schools, the important role that cannot be denied is the role of teachers in class. The teacher has a very important role in designing learning evaluation. As found, every teacher designs the lesson plan with these approaches: fun learning, active learning and students-centered. In a pluralistic community of children need a learning approach in accordance with the needs of children (Uzum \& Avineri, 2019). In a pluralistic Indonesian society where every child who experiences various types of cultures is expected to learn and adapt the main culture of Indonesia as a whole, the learning approach for each child must be studied more deeply in accordance with developments, demands epoch and the needs of children's development (Lestari, 2015).

One of the findings presented in advance in relation to efforts to create a climate of teaching and learning activities in schools, the important role that cannot be denied is the role of teachers in evaluating the learning process. The teacher has a very important role in designing learning evaluation. As found in this research that every teacher designs the evaluation strategy that integrated to learning process as a part of fun learning (El Ashamwi, Sanchez, \& Carmona, 2018; Kwo, 2010). Evaluating the students, not only for academic aspects, but also for all students' involvement to teaching learning activities (Krolak-Schwerdt, Glock, \& Böhmer, 2014; Recepoglu, 2013) as their basic role to take part in maintaining multicultural values along the learning.

In a pluralistic community, children need a learning approach in accordance with their needs where every child who experiences various types of culture is expected to learn to adapt to the main culture Indonesia. The pluralistic awareness between the teachers, especially in the relation to the students' future era, will bring students to get maximum capabilities to interact and alive conveniently (Arifin et al., 2018; Baykova \& Vlasova, 2019; Sleeter, 2018). They will be in a situation where the differences will not be handicaps to go through the life normally, but it will be supposed to a good opportunity to get the future, together with everyone.

\section{Conclusions}

Based on the results and discussion above, it can be concluded as follows: 1) the teacher has a central role in cultivating and integrating values of multicultural values in education, especially in curriculum 2013 implementation; 2) before carrying out teaching and learning activities, the teacher prepares a multicultural based student-centered lesson plan; 3) preparation of multicultural learning designs based can be done through five main stages, they are: (1) content analysis (content analysis); (2) cultural background analysis (setting analysis); (3) material mapping (contents mapping); (4) organizing learning material; and (5) pouring in the learning format; 4) All of these school teachers' learning strategies in integrating multicultural values has been actually a part of curriculum 2013 objective.

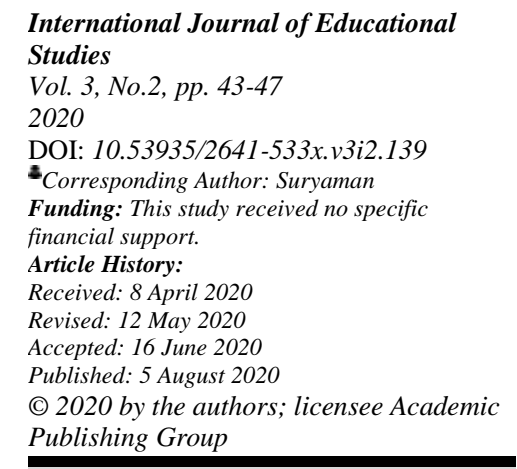

46 


\section{References}

Agus, M. (2016). School strategy in multicultural education. Journal of Elementary School Education, 2(2), 114-130.

Amirin, T. M. (2012). Implementation of a contextual multicultural education approach based on local wisdom in Indonesia. Journal of Educational Development: Foundations and Applications, 1(1).

Anderson, J. B., Swick, K. J., \& Yff, J. (2001). Service learning in teacher education: Enhancing the growth of new teachers. Their Students, and Communities. ERIC.

Arends-Tóth, J., \& van de Vijver, F. (2000). Multiculturalism: Tension between ideal and reality. Dutch Journal of Psychology, 55, $159-168$.

Arifin, I., Juharyanto, Mustiningsih, \& Taufiq, A. (2018). Islamic crash course as a leadership strategy of school principals in strengthening school organizational culture. SAGE Open, 8(3), 215824401879984.

Bakken, J. P., Obiakor, F. E., \& Rotatori, A. F. (2014). Gifted education: Current perspectives and Issues. Retrieved from: https://doi.org/10.1007/s13398-014-0173-7.2.

Banks, J. (2016). Cultural diversity and education. New York: Routledge.

Banks, J., \& Banks, C. (2009). Multicultural education: Issues and perspectives (7th ed.): Wiley.

Baykova, O. V., \& Vlasova, V. K. (2019). Web forum as a condition of skill, social and cultural development of students of translation and interpretation. Department of Universities.

Chang, H., Pak, S. Y., \& Sleeter, C. (2018). Multicultural education: Using our past to build our future. International Journal of Multicultural Education, 20(1), 1-4.

Dale, J., \& Hyssop-Margison, E. J. (2010). Paulo freire: Teaching for freedom and transformations. The philosophical influences on the work of paulo freire. Explorations of Educational Purpose (Vol. 12). Netherlands: Springer.

El Ashamwi, Y. P., Sanchez, M. E. H., \& Carmona, J. F. (2018). Testimonialista pedagogues: Testimonio pedagogy in critical multicultural education. International Journal of Multicultural Education, 20(1), 67-85.

Hernandez, H. (1989). Multicultural education: A teacher's guide to content and process. Columbus: OH: Merrill Publishing Company.

Jablonski, N. G. (2013). Culture evolves. Folia Primatologica, 84(2), 115-117.

Juharyanto. (2012). Implementation of the competence of principals as agents of change in high schools: A multi-case study of three outstanding elementary schools/MIs in bondowoso regency, jember regency and situbondo regency. Ph.D Thesis Universitas Negeri Malang.

Juharyanto. (2014). Internalization of character values in building an educational organizational culture case study at Bondowoso Islamic religious high school. Lantern Education Journal, 1(1), 10-18.

Juharyanto, \& Imron Arifin, E. (2018). Effective leadership on curriculum 2013 implementation in religious based schools. The Journal of Social Sciences Research, 2, 40-48.

Krolak-Schwerdt, S., Glock, S., \& Böhmer, M. (2014). Teachers' professional development: Assessment, training, and learning: Springer Science \& Business Media.

Kwo, O. (2010). Teachers as learners: Critical discourse on challenges and opportunities. Netherlands: Springer.

Lawyer, G. (2018). The dangers of separating social justice from multicultural education: Applications in higher education. International Journal of Multicultural Education, 20(1), 86-101.

Lestari, G. (2015). Bhinnekha tunggal Ika: Khasanah multikultural Indonesia di Tengah Kehidupan SARA. Jurnal Pendidikan Pancasila Dan Kewarganegaraan, 28(1), 31-37.

McGee Banks, C. A., \& Banks, J. A. (1995). Equity pedagogy: An essential component of multicultural education. Theory Into Practice, 34(3), 152-158

Meirink, J. A., Meijer, P. C., \& Verloop, N. (2007). A closer look at teachers' individual learning in collaborative settings. Teachers and Teaching: Theory and Practice, 13(2), 145-164.

Nakaya, A. (2018). Overcoming ethnic conflict through multicultural education: The case of West Kalimantan, Indonesia. International Journal of Multicultural Education, 20(1), 118-137.

Nuhoğlu, H., \& İmamoğlu, Y. (2019). An interdisciplinary nature education program for gifted primary school students and its effect on environmental literacy. Elementary Education Online, 17(4), 1928-1943.

Peris-Ortiz, M., \& Merigo, J. M. (2015). Sustainable learning in higher education. Berlin/Heidelberg, Germany: Springer.

Rahman, A. (2017). Post Islamism Islamic economics in the era of urban and multiculturalism. Islam Realitas: Journal of Islamic \& Social Studies, 1(2), 165-172.

Recepoglu, E. (2013). The significance of assumptions underlying school culture in the process of change. International Journal of Educational Technology in Higher, 4(2), 43- 48.

Sleeter, C. (2018). Multicultural education past, present, and future: Struggles for dialog and power-sharing. International Journal of Multicultural Education, 20(1), 5-20.

International Journal of Educational Studies

Vol. 3, No.2, pp. 43-47

2020

DOI: $10.53935 / 2641-533 x . v 3 i 2.139$

Corresponding Author: Suryaman

Funding: This study received no specific

financial support.

Article History:

Received: 8 April 2020

Revised: 12 May 2020

Accepted: 16 June 2020

Published: 5 August 2020

(C) 2020 by the authors; licensee Academic

Publishing Group
Suryaman, \& Karyono, H. (2017). Leading entrepreneurship education-based primary schools. In 3rd International Conference on Education and Training, 128, 135-139.

Suryaman, \& Karyono, H. (2018). Pengintegrasian nilai-nilai kewirausahaan berbasis multikultural. Sosiohumanika, 11(1), 63-78.

Syam, N. (2009). The challenge of Indonesian multiculturalism: From radicalism to nationalism. Yogyakarta: Kanisius.

Uitermark, J., Rossi, U., \& Van Houtum, H. (2005). Reinventing multiculturalism: Urban citizenship and the negotiation of ethnic diversity in Amsterdam. International Journal of Urban and Regional Research, 29(3), 622-640.

Uzum, B., \& Avineri, N. (2019). Preservice teachers' discursive constructions of cultural practices in a multicultural telecollaboration. International Journal of Multicultural Education, 21(1), 82-104.

Villegas, A. M., \& Lucas, T. (2002). Preparing culturally responsive teachers: Rethinking the curriculum. Journal of Teacher Education, 53(1), 20-32.

Zhu, X., \& Zeichner, K. (2013). Preparing teachers for the 21st century (Vol. 21): Springer. 